\title{
Exploitation of white-lipped peccaries Tayassu pecari (Artiodactyla: Tayassuidae) on the Osa Peninsula, Costa Rica
}

\author{
Mariana Altrichter and Roberval Almeida
}

\begin{abstract}
We studied movements of white-lipped peccaries (Tayassu pecari, Artiodactyla, Tayassuidae) throughout the Osa Peninsula and their use by local people during 1997-2000, using interview techniques. We draw five main conclusions: 1) White-lipped peccaries living on the Osa Peninsula range within Corcovado National Park for most of the year. 2) Peccaries travel beyond the Park boundaries to the north and south-east of the Peninsula at the end of the wet season when a fruit shortage occurs in Corcovado. 3) The local people hunt peccaries as the herds move through the Peninsula. 4) Current small herd sizes observed by locals in the
\end{abstract}

Peninsula and by researchers in the Park may indicate a decline of the peccary population. 5) Peccaries constitute neither an important source of food nor a source of cash income for local people. We suggest that sustainable use of peccaries in this region is neither realistic nor necessary. Instead of trying to legalize and regulate hunting, effective systems to control illegal hunting should be implemented, especially outside the Park boundary from October to January when the animals are on the move.

Keywords Artiodactyla, Costa Rica, exploitation, hunting, peccaries, Tayassu pecari.

\section{Introduction}

Preservation of natural ecosystems in protected areas is considered an effective conservation strategy (Brandon et al., 1998; Bennett \& Robinson, 2000). However, many species, especially larger mammals, need extensive areas to survive, and the national parks of small countries such as Costa Rica rarely achieve this size (Terborgh, 1992, 1999). The reasons why larger mammals need extensive areas vary. Predators often have low densities and large home ranges (Woodroffe \& Ginsberg, 1998), and frugivores, such as white-lipped peccaries Tayassu pecari (Artiodactyla: Tayassuidae), may have migratory or nomadic movements (Kiltie \& Terborgh, 1983; Bodmer, 1990; Sowls, 1997; but see also Fragoso, 1998).

The white-lipped peccary ranges from southern Mexico to northern Argentina (Mayer \& Wetzel, 1987). The average weight of adult white-lipped peccaries is $33 \mathrm{~kg}$ (Sowls, 1997), they are highly mobile, travel in herds of up to 2,000 individuals (Mayer \& Wetzel, 1987; Sowls, 1997), and are generally considered omnivorous,

Mariana Altrichter ${ }^{1}$ (Corresponding author) and Roberval Almeida Programa Regional en Manejo de Vida Silvestre, Universidad Nacional APDO 1350-3000 Heredia, Costa Rica. E-mail: m_altrichter@yahoo.com; ralmeida@una.ac.cr

${ }^{1}$ Present address: School of Renewable Natural Resources, University of Arizona, 104 BioScience East, Tucson, AZ 85721

Received 18 April 2000. Revision requested 30 October 2000 Accepted 28 November 2001 although in Costa Rica they are mainly frugivorous (Altrichter et al., 2000). Over most of their distribution white-lipped peccaries are an important and favourite source of food for indigenous and rural inhabitants (Smith, 1976; Kiltie, 1980; Redford \& Robinson, 1987; Vickers, 1991; Bodmer, 1995; Altrichter \& Jiménez, 1999). Over-hunting and habitat destruction threaten several populations with extinction (Cullen et al., 2000), and the subspecies T. p. spiradens, which inhabits Southern Costa Rica, was considered Vulnerable by the IUCN/SSC Pigs and Peccaries Specialist Group under the pre-1994 IUCN Red List categories and criteria (March, 1993). A reassessment of the Red List status of the subspecies of T. pecari is required (C. Hilton-Taylor, pers. comm.).

In Costa Rica white-lipped peccary populations are isolated in protected areas (Vaughan, 1983; March, 1993), and the largest population in the country lives in a 47,000 ha protected lowland rain forest in Corcovado National Park in the south-western section of the Osa Peninsula (Carrillo, 2000). The Park is surrounded by a Guaymi Indigenous Reserve and the Golfo Dulce Forest Reserve, which covers most of the forested area outside the Park. Within this reserve there are 20 villages. With the exception of the eastern coast, the majority of the Osa Peninsula is little developed. Most of the inhabitants practice small-scale subsistence production of crops and livestock, with very basic commerce. The local people of the Peninsula consume various wild animals, particularly mammals, although hunting is forbidden by law (Altrichter, 2001). 
Twenty years ago the Osa Peninsula was still mostly forested, with abundant wildlife preserved largely as a consequence of the remote and mountainous topography. The elders of the region tell of times when they hunted peccaries from large groups as the herds moved through the Peninsula (Altrichter, 2001). However, despite the fact that nearly $80 \%$ of the Peninsula is legally protected in some form (Cuello et al., 1998), high deforestation rates during the 1980s and an increase in the human population have resulted in a fragmented landscape with depleted wildlife. Although the forest remains continuous along mountain tops and steep hillsides, pastures and crops have replaced most of the forest in valleys outside the Park boundary. Despite this dramatic change in the vegetation pattern of the Peninsula, some peccary herds continue to travel throughout the Peninsula and people continue to hunt them (Cuello et al., 1998).

Several studies have addressed the ecology of peccaries in Corcovado National Park (Altrichter, 1997; Campero, 1999; Altrichter et al., 2000; Carrillo, 2000). However, outside Corcovado, patterns of seasonal movement and distribution of peccaries and their exploitation by humans remain unknown. Such information is required for the creation of a local conservation strategy for peccaries. This strategy could attempt either to implement the sustainable use of peccaries or reinforce hunting prohibitions.

Our objective here is to examine the status of whitelipped peccaries in the Osa Peninsula, and to suggest the most appropriate conservation strategy. We integrate results from a previous study, about the importance of wild mammals for the diet of local people in the Osa Peninsula (Altrichter, 2001), with new data about the distribution of peccaries and their exploitation outside the Park.

\section{Methods}

We conducted interviews with local people living in 15 villages of the Osa Peninsula, located in the southwestern Pacific coast of Costa Rica, from 1998-2000. In this study, we analyze a data set that combines this work with interviews from a previous study conducted in 1997 in 17 additional villages on the Peninsula (Altrichter, 2001). This description of our methods applies to both research periods. Every village on the Peninsula was included in the study except for the largest one, Puerto Jiménez. This coastal village, surrounded by tourism development and agriculture, was not included because its inhabitants make little use of wildlife (pers. obs.). Sizes of villages range between three and 60 households. We interviewed all the house- holds of each village, with the exception of those where adults were absent or the family had lived in the region for $<1$ year. To obtain general information about the consumption of game and domestic meats in the Peninsula we conducted 327 interviews, representing approximately $57 \%$ of the households of the entire Osa Peninsula. Semi-structured interviews (Bernard, 1995) were conducted in Spanish (our native language) and lasted as long as necessary to obtain the desired information. One of us (R.A.) has been working in this area for five years and is well known and trusted by the local people. In those villages where both of us were unknown we visited for several days, in order to build a rapport with the inhabitants, before beginning our interviews.

We interviewed one adult from each family that we visited, and we assumed that this information represented the habits of the entire family. Using individual households as the sampling unit, we calculated an index of relative consumption frequency for five different types of meat (pork, chicken, beef, fish and game meat) with values ranging from five (most often consumed) to zero (not consumed). From this we obtained a mean relative consumption frequency for each type of meat. Although local people consume several species of game, nearly everyone eats two species in particular: paca Agouti paca and white-lipped peccary. Therefore, we chose to gather consumption frequencies for these two species by estimating the average number of times these species were consumed per village per year.

The interviews were also used to gather information about peccaries, including their movement patterns on the Peninsula, population trends and uses by local people. However, to gather more specific information on movements and exploitation of peccaries, we conducted additional in-depth interviews (Bernard, 1995) with 25 key informants from different households and villages. When necessary, we returned to these individuals to ask follow-up questions. Key informants were people such as hunters and elders who we considered to have a superior knowledge of peccary habits, peccary population trends and hunting pressures. Most of the key informants had been living in the Peninsula since its colonization, c. 20 years ago. Hunting is illegal and so it was possible that hunters might not provide accurate information regarding their hunting habits; we therefore corroborated their information with neighbours and village leaders. Ninety per cent of the hunter's information was verified by independent sources. In those cases where the accuracy of the information was dubious it was not included in our analysis.

We estimated the peccary movement patterns outside the Park from the frequency of peccary sightings by local people. For each village that we visited we estimated the 
average frequency of sightings and assigned the village to one of four categories: a) no sightings; b) sightings once every 2 years; c) every year; and d) twice a year. In addition, we spent 35 non-consecutive days surveying forested areas outside the National Park that, according to local people, were used by peccaries. The survey was non-systematic, and normally consisted of 4-6 h of walking in the forest, looking for peccaries and their tracks.

To estimate the number of white-lipped peccaries that are killed by a given village in a single season (September-December 2000), we visited six of the closest villages to the Park twice a month. From informal interviews with 12 hunters and 23 inhabitants we estimated the number of white-lipped peccaries that were killed by locals, the number of herds and the approximate size of those herds that passed by near these villages, and the approximate number of hunters from outside the Peninsula that visited the region during this four-month period. However, it was not possible to determine whether different sightings of peccary herds were really different herds, or whether the same herds were seen repeatedly.

\section{Results}

Most of the people (85\%) interviewed mentioned that white-lipped peccaries are not observed all year round but only during a short period at the end of the wet season (October-December) when the peccaries pass near villages. Survey data indicated that peccary sightings diminish with distance from the Park boundary. People living immediately adjacent to the Park stated that they normally observe peccaries at least twice per year. People living close to the Park $(1-10 \mathrm{~km})$ mentioned peccary sightings approximately once per year. In distant villages (10-25 km from the Park) peccaries are sighted only once every $2-3$ years. Peccaries are not sighted in those villages that are on the coast, further than $25 \mathrm{~km}$ from the Park, or in deforested areas (Fig. 1). During our surveys in the forested areas outside the National Park, we only found tracks and/or groups at the end of the wet season.

According to reported sightings, and our own observations of peccaries and tracks, we were able to identify two different movement patterns across the Park boundary: a) peccaries regularly use areas adjacent
Fig. 1 Study area showing the location of each village where interviews were conducted and the frequency of peccary sightings around each village. Small arrows show hypothesized regular year-round movements of peccaries in and out of Corcovado National Park. Large arrows show hypothesized seasonal long-distance movements of peccaries in and out of the Park.

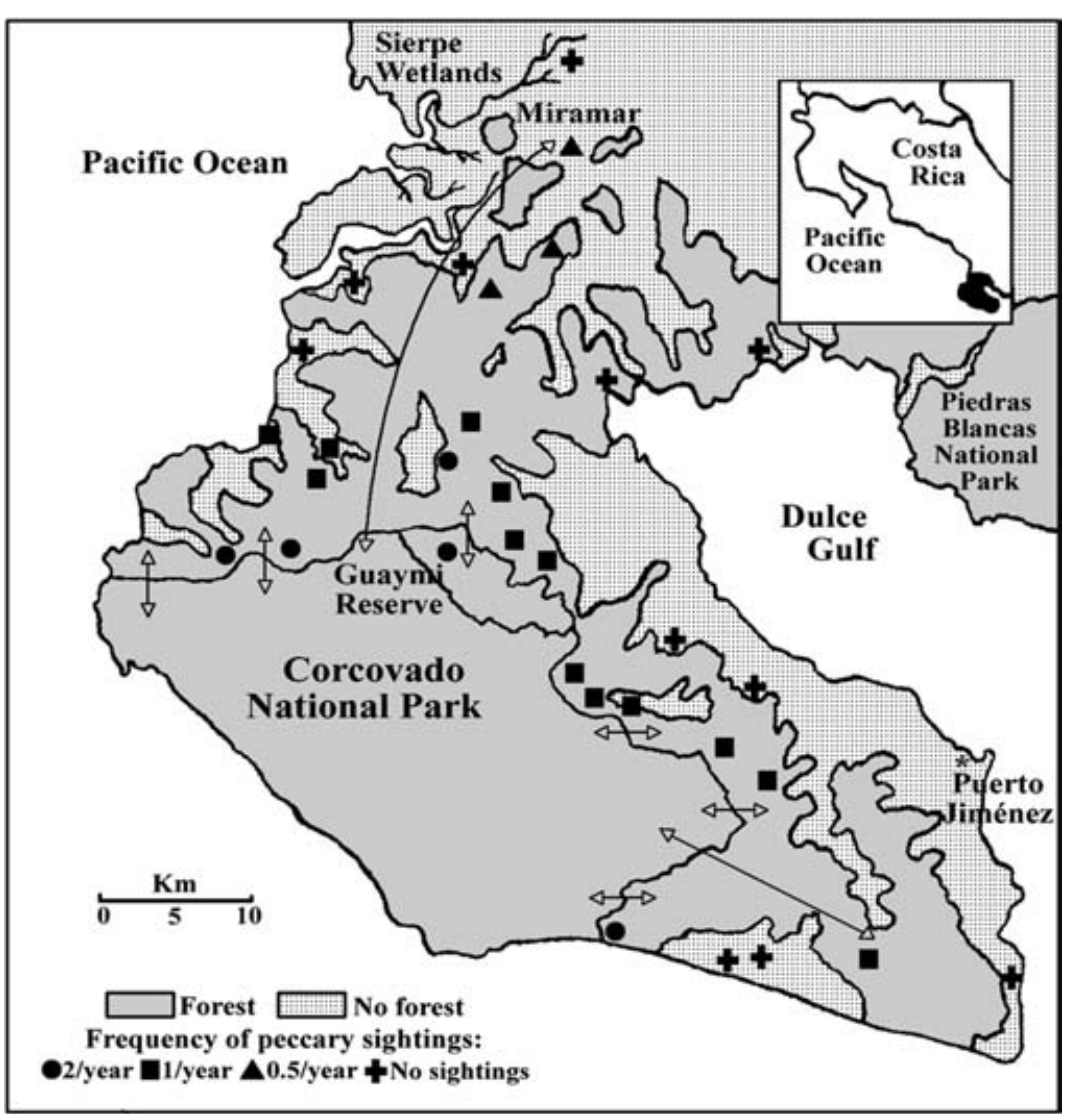

() $2002 \mathrm{FFI}$, Oryx, 36(2), 126-132 
to the Park boundary, and b) peccaries annually move from inside the Park to the north and south-east regions of the Peninsula. The movement to the south-east is approximately half the distance travelled to the north (Fig. 1).

All the key informants that we interviewed spoke of diminishing peccary group sizes and frequency of sightings over the last two decades. At the time when the Peninsula was colonized, group sizes were commonly 200-500 individuals and peccaries were observed yearround. Today, however, group sizes are 10-80 animals and on rare occasions up to 200. All the hunters that we interviewed implicated hunting as the cause of the peccaries' decline.

Local people hunt peccaries mainly for consumption, although peccary meat is consumed much less frequently than meat of domestic animals (Table 1). Paca is the most frequently consumed game meat on the Peninsula $($ mean $=3.7$ occasions per household per year, $\mathrm{SD}=1.2)$ followed by the white-lipped peccary $($ mean $=0.33$ occasions per household per year, $\mathrm{SD}=0.15$; between species Mann-Whitney $U=128.5, P<0.01$ ). Other species, such as collared peccary Tayassu tajacu, agouti Dasyprocta punctata, coati Nasua narica, and red brocket deer Mazama americana, are consumed much less frequently and by fewer people. Of all the families interviewed, $28 \%$ consume peccary meat at least once per year, $43 \%$ once every $2-3$ years and the rest consume peccary occasionally or never. The frequency of peccary consumption decreases with distance from the Park (Kruskal-Wallis $\mathrm{H}=25.7, P<0.01$; Table 2) because

Table 1 Mean relative consumption frequency (on a scale of $0-5$ ) of different types of meat in the Osa Peninsula \pm SD.

\begin{tabular}{ll}
\hline Meat & Relative consumption \\
\hline Pork & $4.22 \pm 0.91$ \\
Chicken & $4.13 \pm 0.92$ \\
Beef & $3.32 \pm 0.89$ \\
Fish & $1.25 \pm 1.71$ \\
Game & $0.98 \pm 1.13$ \\
\hline
\end{tabular}

Table 2 Mean frequency of consumption of peccary meat per year per household \pm SD in villages at different distances from Corcovado National Park

\begin{tabular}{lcl}
\hline $\begin{array}{l}\text { Distance from } \\
\text { Park }(\mathrm{km})\end{array}$ & $\begin{array}{l}\text { Number of villages } \\
\text { (Number of households } \\
\text { interviewed) }\end{array}$ & $\begin{array}{l}\text { Frequency of } \\
\text { consumption }\end{array}$ \\
\hline On the boundary & $7(58)$ & $1.74 \pm 0.15$ \\
$1-10$ & $13(164)$ & $0.72 \pm 0.14$ \\
$11-20$ & $7(63)$ & $0.32 \pm 0.10$ \\
$21-30$ & $4(29)$ & $0.17 \pm 0.11$ \\
$30-35$ & $1(13)$ & 0 \\
\hline
\end{tabular}

people hunt them opportunistically. When a peccary herd moves near a village the news spreads rapidly and anyone with a gun searches intensively for the animals in adjacent forested areas.

According to older hunters, larger proportions of the herds are now killed than in the past. In 1999 we learned that 17 of 30 peccaries were killed in a single hunt near one village. From September to December 2000 we collected 11 reports of peccaries passing by the six villages closest to the Park. We estimate that local hunters killed 89 peccaries during this period. We were unable to identify whether these 11 sightings represented different herds, but by using the reported group sizes before the hunts and the number of peccaries killed from each group, we were able to estimate that $20-60 \%$ of animals were killed on each occasion. This estimation of mortality does not include any killings by the approximately 45 hunters from outside the Peninsula that visited the region during this period.

\section{Discussion}

According to the local people the presence of peccary herds outside Corcovado National Park at the end of the wet season (October-December) is an annual event. In a previous study four herds of peccaries were followed with radiotelemetry in Corcovado National Park, and it was found that peccaries travelled longer distances in October and early November (c. $5 \mathrm{~km}$ daily) than in other months (Altrichter, 1997). In mid-November three of the tracked groups left the study area in the Park, and even with aerial radio tracking over the Park, covering an area corresponding to approximately three-quarters of the entire Park, it was impossible to locate them. By January 1997 the groups had returned to the area, but each group was reduced to about half its former size (Altrichter, 1997). This disappearance of groups from the study area late in the wet season also occurred in the next two years (J. Villalobos \& R. Arias, pers. comm.).

The timing and location of peccary sightings by local people give no indication that any peccary herds live permanently beyond the Park boundary. Our results suggest that those peccaries that inhabit the Peninsula range within the Park throughout most of the year, but during the end of the wet season may move beyond the Park boundary to the forested regions of the central and south-eastern Peninsula (Fig. 1). The area near Miramar, approximately $25 \mathrm{~km}$ north of the Park boundary, appears to be the northern limit of distribution of peccaries on the Osa Peninsula (Fig. 1). Natural barriers to the west and north (Sierpe River and its mangrove forests) and urban development to the east and north probably impede the movement of peccaries further afield. 
The long-distance movements of peccaries at the end of the wet season (October-December) coincide with a period of low fruit quantity and diversity in Corcovado National Park (Boinski, 1986; Altrichter, 1997; Altrichter et al., 2001a). Peccaries in Corcovado are mainly frugivorous but switch to stems and leaves when fruits are scarce in October and November (Altrichter et al., 2000, Altrichter et al., 2001a). This dietary change towards lower quality forage (López, 1999) and the presence of peccaries outside the Park specifically during this period may indicate that low fruit availability induces long distance travel. These movements may, in turn, increase the exposure of the peccary herds to hunting.

It is likely that peccaries increase their home-range during the period of fruit shortage in order to increase their probability of finding fruits (Fragoso, 1998), probably travelling along historic circuits that remain relatively intact. Although there are currently two movement patterns of peccaries from the park, one to the north and the other to the south-east, in the past, when the whole Peninsula was forested, peccaries might have inhabited the entire region and moved in all directions. Such movements might have facilitated occasional genetic mixing with populations from the rest of the country.

The limited use of white-lipped peccaries by local people in the Osa Peninsula suggests that peccaries are not an indispensable, nor even an important, source of protein and/or cash. This usage differs from other regions in Latin America, such as the Amazon, where people rely heavily on peccaries for food and as a source of income (Bodmer et al., 1990; Bodmer et al., 1997; Sowls, 1997). In the Osa Peninsula domestic animals are the main source of meat for local people; game meats are eaten much less frequently (Table 1). Local people consume six species of wild mammals, but only four are favoured (Altrichter, 2001). This selective consumption differs from South America where a large diversity of wild mammals is consumed (Redford \& Robinson, 1987; Bodmer, 1995; Mena et al., 2000; Hill \& Padwe, 2000). Another indication of the limited importance of peccaries for the local people in the Osa Peninsula is that people do not actively seek peccaries but instead hunt them opportunistically when herds pass near villages. Furthermore, peccaries do not constitute a cash income because no important trade in meat or hide exists.

Although frequency of consumption of peccaries is low, hunting pressure is high when it does occur. The high proportion of a herd that can be harvested in a single season suggests that this level of hunting pressure is probably unsustainable. Although we do not know what proportion of the population of peccaries in the Park leaves the Park boundaries, we do know that most of the herds travelling through the Peninsula encounter high hunting mortality. The same herd may be hunted by different groups of hunters as it passes different villages in the Peninsula. It is likely that the proportion of a herd harvested in a single hunting event has increased over the past decades because of increased access to more powerful weaponry. Indeed, one of the hunters kills peccaries with a machine gun. Harvesting methods of this sort that are capable of eliminating a large proportion of a herd could disrupt the group's social organization and survival (Peres, 1996). By the end of the wet season most females are not gravid but they are lactating (Altrichter et al., 2001b). If these females are killed, the population would lose two or three animals if young are unable to survive. The approximately 50\% reduction in the groups' sizes after their return to the study area in Corcovado reported by Altrichter (1997) was probably the result of hunting while the peccaries were at or beyond the Park boundary. Natural predation might also account for these decreasing numbers, but such high rates of mortality in such a short period are unlikely. It is also possible that previously large herds split into smaller subgroups during the period of low fruit availability, but one might expect to see more herds of smaller numbers upon their return, which was not the case (Altrichter, 1997).

There is evidence that suggests that the population of white-lipped peccaries in the Peninsula is declining. Group sizes have diminished; in Corcovado during the last four years there have been no sightings of groups larger than 70 individuals, and group size tends to be 18-30 ( $\mathrm{n}=10$ groups; Altrichter, 1997; J. Villalobos, pers. comm.). These numbers are small in comparison with the sizes of white-lipped peccary groups reported from other tropical regions (30-200; Peres, 1996; Sowls, 1997; Fragoso, 1998), and estimates from Corcovado in 1975 of herds with over 1,000 individuals (Vaughan, 1981). If the herd size is indicative of the total density of animals within a particular region (Donkin, 1985) these data may indicate a population decline. With smaller herd sizes hunting pressure may become proportionally more significant on the peccary population and extinction probabilities may increase (Lawton, 1995). The longdistance movements of white-lipped peccaries and high hunting pressure in the Osa Peninsula could lead to the extinction of this population despite the existence of a protected area (Peres, 1996).

Although sustainable use of peccaries is occurring in community-based conservation strategies in the Amazon region (Bodmer, 1994; Bodmer et al., 1997; Robinson \& Bodmer, 1999; Bodmer \& Puertas, 2000), the ecological and socio-economic situation in the expanse of the Amazon is different from that in Costa Rica. The current use of white-lipped peccaries by local people in the Osa Peninsula suggests that people do not hunt for 
subsistence and that enforcement of the hunting prohibition would not adversely affect their diets or income. Furthermore, on the Osa Peninsula conditions are not conducive to the sustainable use of peccaries because of the relatively small size of Corcovado National Park, the recent declines in peccary populations within the Peninsula and the high human impact immediately beyond the Park boundaries.

There are limited options for the conservation of white-lipped peccaries on the Osa Peninsula. As is the case with large carnivores (Woodroffe \& Ginsberg, 1998), the highest mortality of peccaries may occur when they range beyond the Park borders. Even if it were possible to extend the size of the Park, it could not include all the areas that peccaries currently use on the Peninsula because of patterns of human occupation. A long-term strategy should promote systems of protected areas on private lands that are currently used by peccaries during their seasonal movements. However, the most effective and efficient short-term strategy requires the reinforcement of existing hunting regulations, with patrols focused on forested regions beyond the Park boundary and concentrated from October to December when peccaries are on the move.

\section{Acknowledgements}

We thank the communities for sharing their knowledge with us. We specially thank R. Bodmer, W. Eberhard, J. Dalling, P. Sherman and G. Barrantes for their comments and suggestions to improve earlier drafts. We also thank three anonymous reviewers for their insightful comments and Camilla Erskine for her valuable support. We thank Eduardo Baldioceda for field assistance. This research was partially supported by US Fish \& Wildlife Service, TNC (The Nature Conservancy), Lincoln Park Zoo, WWF and IUCN.

\section{References}

Altrichter, M. (1997) Estrategia de alimentación y comportamiento del chancho cariblanco (Tayassu pecari) en un bosque húmedo tropical de Costa Rica. MSc Thesis, National University, Heredia, Costa Rica.

Altrichter, M. (2001) Importancia de mamíferos silvestres en la dieta de pobladores de la Península de Osa, Costa Rica. Revista Mexicana de Mastozoología, 4, 105-111.

Altrichter, M. \& Jiménez, I. (1999) Caza y consumo de carne de monte en San Juan del Norte, Reserva Biológica Indio-Maíz, Nicaragua. Mesoamericana, 4, 117-126.

Altrichter, M., Sáenz, J., Carrillo, E. \& Fuller, T. (2000) Dieta estacional de Tayassu pecari (Artiodactyla: Tayassuidae) en el Parque Nacional Corcovado, Costa Rica. Biología Tropical, 48, 689-702.
Altrichter, M., Carrillo, E., Sáenz J. \& Fuller, T. (2001a) White lipped peccary (Tayassu pecari) diet and fruit availability in a Costa Rican rain forest. Biología Tropical, 49, 1105-1114.

Altrichter, M., Drews, C., Sáenz, J. \& Carrillo, E. (2001b) Sex ratio and breeding of white-lipped peccaries Tayassu pecari (Artiodactyla: Tayassuidae) in a Costa Rican rain forest. Biología Tropical, 49, 381-387.

Bennett, E.L. \& Robinson, J. (2000) Hunting for the snark. In Hunting for Sustainability in Tropical Forests (eds J.G. Robinson \& E.L. Bennett), pp. 1-9. Columbia University Press, New York.

Bernard, H.R. (1995) Research Methods in Anthropology: Qualitative and Quantitative Approaches. 2nd Edn. AltaMira Press, London.

Bodmer, R.E. (1990) Responses of ungulates to seasonal inundations in the Amazon floodplain. Journal of Tropical Ecology, 6, 191-201.

Bodmer, R.E. (1994) Managing wildlife with local communities in the Peruvian Amazon: the case of the Reserva Comunal Tamshiyacu-Tahuayo. In Natural Connections: Perspectives in Community-based Conservation (eds D. Western \& R.M. Wright), pp. 113-134. Island Press, Washington, DC.

Bodmer, R.E. (1995) Managing amazonian wildlife: biological correlates of game choice by detribalized hunters. Ecological Applications, 5, 872-877.

Bodmer, R.E. \& Puertas, P. (2000) Community-based comanagement of wildlife in the Peruvian Amazon. In Hunting for Sustainability in Tropical Forests (eds J.G. Robinson \& E.L. Bennett), pp. 395-409. Columbia University Press, New York.

Bodmer, R.E., Bendayán, N.Y., Moya, A.L. \& Fang, T.G. (1990) Manejo de ungulados en la Amazonía Peruana: Analisis de su caza y comercialización. Boletin de Lima, 70, 49-56.

Bodmer, R.E., Aquino, R., Puertas, P., Reyes, C., Fang T.G. \& Gottdenker, N. (1997) Manejo y uso Sustentable de Pecaríes en la Amazonía Peruana. IUCN, Quito, Ecuador.

Boinski, S. (1986) The ecology of squirrel monkeys in Costa Rica. PhD Thesis, University of Texas, Austin.

Brandon, K., Redford, K.H. \& Sanderson, S.E. (1998) Introduction. In Parks in Peril (eds K. Brandon, K.H. Redford \& S.E. Sanderson), pp. 5-23. Island Press, Washington, DC.

Campero, H. (1999) Variación y estructura genética dentro y entre grupos de chanchos de monte (Tayassu pecari) en el Parque Nacional Corcovao, Costa Rica. MSc Thesis, National University, Heredia, Costa Rica.

Carrillo, E. (2000) Ecology and conservation of white-lipped peccaries and jaguars in Corcovado National Park. PhD Thesis, University of Massachusetts, Amherst, Massachusetts.

Cuello, C., Brandon, K. \& Margoluis, R. (1998) Costa Rica: Corcovado National Park. In Parks in Peril (eds K. Brandon, K.H. Redford \& S.E. Sanderson), pp. 143-191. Island Press, Washington, DC.

Cullen, L.J., Bodmer, R.E. \& Padúa, C.V. (2000) Effects of hunting in habitat fragments of the Atlantic forests, Brazil. Biological Conservation, 95, 49-56.

Donkin, R.A. (1985) The Peccary: with Observations on the Introduction of Pigs to the New World. The American Philosophical Society, Philadelphia.

Fragoso, J.M. (1998) Home range and movement patterns of white-lipped peccary (Tayassu pecari) herds in the Northern Brazilian Amazon. Biotropica, 30, 458-469. 
Hill, K. \& Padwe, J. (2000) Sustainability of Aché hunting in the Mbaracaya Reserve, Paraguay. In Hunting for Sustainability in Tropical Forests (eds J. Robinson \& E.L. Bennett), pp. 79-105. Columbia University Press, New York.

Kiltie, R.A. (1980) More on Amazon cultural ecology. Current Anthropology, 21, 541-546.

Kiltie, R.A. \& Terborgh, J. (1983) Observations on the behavior of rain forest peccaries in Peru: why do white-lipped peccaries form herds? Zeitschrift fuer Tierpsychologie, 62, 241-255.

Lawton, J.H. (1995) Population dynamic principles. In Extinction Rates (eds J.H. Lawton \& R.M. May), pp. 147-163. Oxford University Press, Oxford.

López, M.T. (1999) Aspectos nutricionales de la dieta del chancho de monte (Tayassu pecari) en el Parque Nacional Corcovado, Costa Rica. MSc Thesis, National University, Heredia, Costa Rica.

March, I.J. (1993) The White-lipped Peccary (Tayassu pecari). In Pigs, Peccaries and Hippos: Status Survey and Conservation Action Plan (ed. W.L.R. Oliver), pp. 13-22. IUCN/SSC Pigs and Peccaries Specialist Group and the IUCN/SSC Hippo Specialist Group. Gland, Switzerland.

Mayer, J.J. \& Wetzel, R.M. (1987) Tayassu pecari. Mammalian Species, 293, 1-7.

Mena, P.V., Stallings, J.R., Regalado, J.B. \& Cueva, R.L. (2000) The sustainability of current hunting practices by the Huaorani. In Hunting for Sustainability in Tropical Forests (eds J.G. Robinson \& E.L. Bennett), pp. 57-78. Columbia University Press, New York.

Peres, C.A. (1996) Population status of white-lipped Tayassu pecari and collared peccaries T. tajacu in hunted and unhunted amazonian forests. Biological Conservation, 77, $115-123$.

Redford, K.H. \& Robinson, J.G. (1987) The game of choice: patterns of Indian and colonist hunting in the Neotropics. American Anthropology, 89, 650-667.

Robinson, J.G. \& Bodmer, R.E. (1999) Towards wildlife management in tropical forests. Journal of Wildlife Management, 63, 1-13.

Smith, N.J. (1976) Utilization of game along Brazil's Transamazon highway. Acta Amazonica, 6, 455-466. Sowls, L.K. (1997) Javelinas and other Peccaries, their Biology, Management and Use. 2nd Edn. The University of Arizona Press, Tucson, Arizona.
Terborgh, J. (1992) Maintenance of diversity in tropical forests. Biotropica, 24, 283-289.

Terborgh, J. (1999) Requiem for Nature. Island Press, Washington, DC.

Vaughan, C. (1981) Parque Nacional Corcovado. Plan de manejo y desarrollo. EUNA, Heredia, Costa Rica.

Vaughan, C. (1983) A Report on Dense Forest Habitat for Endangered Wildife Species in Costa Rica. Unpublished report, Environmental Science School, National University, Heredia, Costa Rica.

Vickers, W. (1991) Hunting yields and game composition over ten years in an Amazonian village. In Neotropical Wildlife Use and Conservation (eds J.G. Robinson \& K.H. Redford), pp. 53-81. The University of Chicago Press, Chicago, Illinois. Woodroffe, R. \& Ginsberg, J.R. (1998) Edge effects and the extinction of populations inside protected areas. Science, 280, 2126-2128.

\section{Biographical sketches}

Mariana Altrichter studied the foraging and breeding behaviour of white-lipped peccaries in Costa Rica's lowland rainforests from 1996-1997 as a masters student at the National University of Costa Rica. From 1998-2000 she focused on wild mammal conservation related to indigenous and peasant hunting pressures in Costa Rica. She is currently a Ph.D. student at the University of Arizona where her dissertation assesses conservation problems of the three species of peccaries in the Argentinean Chaco from a biological and anthropological perspective.

Roberval Almeida's main interests include the conservation of large mammals and their relationship with humans. Previously working on primate conservation in Brazil, he now studies ecology of jaguars and their interactions with local peoples in Costa Rica. In addition, he is studying the biological and social implications for Costa Rica of the Mesoamerican Biological Corridor. He is also pursuing the creation of private wildlife refuges as a conservation strategy in Costa Rica. 